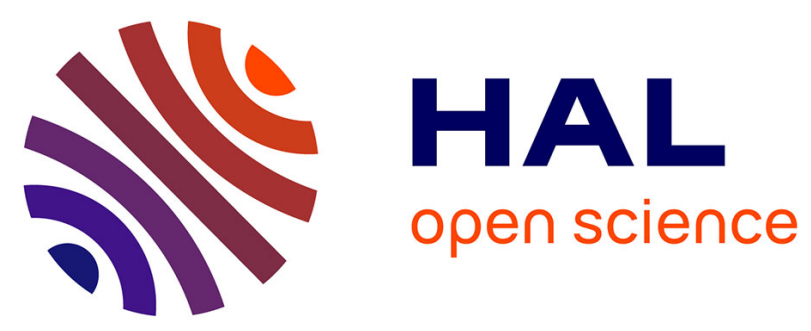

\title{
2nd Euro-mediterranean symposium on fruit and vegetable processing: An integrated view on sustainability and how it can interact with quality, safety and consumers
}

Catherine M.G.C. Renard, Carine Le Bourvellec

\section{To cite this version:}

Catherine M.G.C. Renard, Carine Le Bourvellec. 2nd Euro-mediterranean symposium on fruit and vegetable processing: An integrated view on sustainability and how it can interact with quality, safety and consumers. LWT - Food Science and Technology, 2017, 85 - Part B, pp.283. 10.1016/j.lwt.2017.05.080 . hal-01607140

\author{
HAL Id: hal-01607140 \\ https://hal.science/hal-01607140
}

Submitted on 26 May 2020

HAL is a multi-disciplinary open access archive for the deposit and dissemination of scientific research documents, whether they are published or not. The documents may come from teaching and research institutions in France or abroad, or from public or private research centers.
L'archive ouverte pluridisciplinaire HAL, est destinée au dépôt et à la diffusion de documents scientifiques de niveau recherche, publiés ou non, émanant des établissements d'enseignement et de recherche français ou étrangers, des laboratoires publics ou privés.

\section{다(1)(2)}

Distributed under a Creative Commons Attribution - ShareAlikel 4.0 International 


\section{2nd Euro-mediterranean symposium on fruit and vegetable processing: An integrated view on sustainability and how it can interact with quality, safety and consumers}

To enhance sustainability in fruit and vegetable (F\&Veg) processing, interdisciplinary research is needed to bridge the gaps between safety, quality, nutrition, production, consumer science and process engineering. The aims of this interdisciplinary symposium were to identify current research results that can contribute to inventing more sustainable ways to process F\&Vegs and deliver them to consumers. These sustainable processes should allow at least the same levels of quality, safety, convenience and consumer acceptability than the existing processes while decreasing losses and waste. Part of the symposium was devoted to research questions specific to F\&Vegs including interest in them as sources of micronutrients and questions on the bioaccessibility of these same micronutrients. The symposium also aimed to consider questions about their intrinsic variability and the rapid evolution of the raw material. Another issue is to ensure that processed F\&Vegs can take their true place in food patterns, contributing to the nutritional aim of 5 F\&Vegs per day in the face of disaffection by younger generations.

This symposium occurred from 4 to 6 April 2016 in Avignon. It gathered 210 researchers and students from all over Europe, with strong contingents from Italy, Spain and Poland, in addition to local French participants. Participation from Mediterranean countries was modest, but participants from Turkey, Algeria and Morocco were present. There were also participants from Nigeria, USA, China, Mexico, Canada and Brazil.

The scientific programme was built along four topics, each of which was introduced by an invited conference participant:

Innovative processes for improved sustainability, introduced by Prof. Heny Jäger with a presentation on "Innovative technology options for resource efficient and high quality fruit and vegetable processing"

Quality at the heart of sustainable markets for F\&Veg products, introduced by Prof. Cristina Garcia-Viguera, with a presentation on "Changes in phytochemicals during fruit and vegetable processing"

Constraints on F\&Veg processing: microbial, safety and waste management issues, introduced by Prof. Ana Allende with a presentation on "Ready-to-eat vegetables: current problems and potential solutions to reduce microbial risks in the production chain"

Consumer preferences and needs - OPTIFEL sponsored session, introduced by Dr. Isabelle Maître with a conference on "Are fruits and vegetables good candidates for an appealing diet for the elderly?"
There were a total of 37 oral presentations, of which eight were presented by sponsored young researchers from Nigeria, Romania, Portugal, Italy and Great Britain, and there were 104 posters.

The symposium finished with a round table on sustainability for fruit and vegetable processing in which aspects of raw material availability and variability, consumer attractiveness and support for nutritional claims, relating new processes to nutritional quality, were discussed. Two major factors were identified. One is that most of the publications related to F\&Veg processing are product- and not process-oriented, so data are rarely collected on the actual energy and water usage for example. In addition, the incentive for life cycle analyses dealing with the process itself are low because the major impacts are usually at the production stage. This is true for most agricultural commodities but is even more relevant for F\&Veg than for products such as cereals. This is also a prerequisite to identifying the steps that should be replaced or complemented. Another incentive concerned the lack of reference process against which to compare new propositions, notably in terms of nutritional composition. The nutritional data for processed F\&Veg, probably because of the many potential causes for variability, is poorly documented, with very abundant data for certain nutrients in certain F\&Vegs, but almost none for the same nutrients in other products. Construction of a holistic database on nutrient composition thus appears to be needed. Concerning the incorporation of new technologies in F\&Veg processing, two points can be considered: the acceptance of new technologies by consumers and the demand of consumers for more local and low scale technologies, which is often in contradiction with efficiency. Clearly, there are challenges concerning the modularity and versatility of equipment and decreasing energy and water use.

Unfortunately, the weather in Avignon was not very cooperative, with rain and wind, but the participants still enjoyed a visit to the old town (during a lucky sunny break).

Catherine M.G.C. Renard*, Carine Le Bourvellec UMR408 SQPOV «Sécurité et Qualité des Produits d'Origine Végétale », INRA, Avignon University, F-84000 Avignon, France

* Corresponding author. E-mail address: catherine.renard@inra.fr (C.M.G.C. Renard). 